\title{
Establishment of Alcohol Sales Licensing Regime
}

\author{
Xiaoming Lv \\ Law School,Shandong University of Technology \\ Zibo, China \\ Email: lvxiaoming369 [AT] 163.com
}

\begin{abstract}
Given the very nature of alcoholic drinks and the need to regulate market order, it is both necessary and feasible to establish a unified national licensing regime for alcohol sales. Such a regime shall be applicable to all segments of alcohol sales, including retailing and online sales.
\end{abstract}

Keywords--- Alcohol, Sales License, Administrative License

\section{INTRODUCTION}

China is a major producer and consumer of alcoholic products, sales volume of which keeps growing steadily with the development of the country's economy. Meanwhile, a number of serious problems - like too many players, disorder, as well as counterfeiting — are being exposed on the market. There is an urgent need for strengthened governmental regulation of alcohol sales, while setting up an alcohol sales licensing regime should become an important solution thereto.

\section{NECESSITY TO ESTABLISH AN ALCOHOL SALES LICENSING REGIME}

In the field of alcohol circulation, no unified licensing regime has been established in China. Taking account of the characteristics of alcohol circulation itself and the status quo thereof, it is necessary for the country to set up a licensing regime in this field.

(1) Particularities of alcoholic demand a sales licensing regime

Alcohol is narcotic and addictive, which makes it special as consumer goods. Drinking alcohol of below-standard quality results in harm to human body and even leads directly to death. Alcohol is highly profitable, and this induce many lawbreakers to take risks to sell fake and inferior commodities, which not only disrupt normal circulation, but also threatens health of citizens. The particularities of alcohol require monitoring of alcohol sales, thus improving safety awareness of relevant business organizations and personnel, eliminate potential safety hazards, and ensure the health of citizens and the safety of their life and property.

(2) Establishing an alcohol sales licensing regime is the need of regulating market order

The profitability of alcohol could lead to extensive circulating of fake and inferior alcohol on the market. Some alcohol business organizations have very poor conditions, fail to make correction even after being punished repeatedly. However, due to the absence of sales license system, the punishment imposed by alcohol regulators can only take the forms confiscation and fines, but not suspension of dealership granted by industrial and commercial departments. Such situation provides no sufficient deterrent to illegal alcohol sales.

By establishing administrative license, and through examination of business conditions of alcohol sales applicants by administrative agencies, essential capabilities of market players are ensured and transactions secured. On the other hand, the establishment of sales license enables regulating of business activities in the field of alcohol circulation, strengthens monitoring of sales of fake and inferior alcohol products, both of great significance to establish a safe and fair market environment and to maintain the order of alcohol sales market. ${ }^{[1]}$

(3) Market mechanism itself can hardly effectively eliminate risks of alcohol sales

The market has its own law of operation. The government should reduce direct intervention in the economy and promote free competition on the market. On the alcohol market, the instinctive pursuit for profits makes alcohol sellers likely ignore and may cause huge and irreparable damage to others and society. This kind of risk is difficult to eliminate by the market mechanism itself. Under such situation, the government must regulate and control the alcohol sales market in order to protect public interest. 


\section{SCOPE OF APPLICATION OF ALCOHOL SALES LICENSE}

So far, 16 provinces in China have adopted local regulations on alcohol circulation, each of which includes an administrative licensing system. ${ }^{[2]}$ Local governments of the country have made active exploration in legislation and practice of alcohol sales license, and accumulated much experience, which laid a solid foundation for the central government to establish a unified national alcohol sales license system. A uniform alcohol sales license shall apply to all segments of alcohol sales.

(1) Alcohol sales license applies to both wholesale and retail activities

It is of no dispute that wholesale of alcohol requires a license, while localities differ in their attitudes regarding whether retail activities shall be governed by such a regime. Retailing is the final step for alcohol entering the market. Illegal behaviors in wholesale also exist in retailing. Therefore, health, life and property safety also require a licensing system for retailing.

(2) Licensing system shall apply to online sales

Online sales represent only a special form of sales, and it is not essentially different from traditional mode of sales. Illegal business activities also occur in online sales. The manifestation and harm thereof are similar to those of traditional illegal activities, such as making and selling fake, false propaganda, etc. Therefore, the necessity of applying license system to online sales of alcohol still exists. Online sales of alcohol should obtain license. In addition, online operation often requires no premise, which brings difficulties to regulation by administrative agencies. However, difficulties for regulators can be solved by strengthening law enforcement and improving law enforcement methods, and they constitute no valid reason to opt out such a system.

\section{CONCLUSION}

Current situation of alcohol circulation and the development of market economy in China urgently need to establish a unified national alcohol sales license system to ensure the safety of alcohol consumption. Such a system will plays a positive role in market regulation.

\section{REFERENCES}

[1] Jinsheng Shen: liquor circulation needs to speed up legislation[1], Beijing watch. No.6,pp52,2008.

[2] Shiming Zeng : Liquor legislation and supervision is the inevitable requirement of scientific development[1], Wuhan business[J]. No.11,pp23, 2010. 